Supplement of Clim. Past, 17, 379-396, 2021

https://doi.org/10.5194/cp-17-379-2021-supplement

(c) Author(s) 2021. This work is distributed under

the Creative Commons Attribution 4.0 License.

(c) (1)

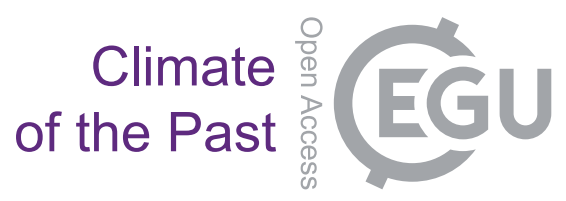

Supplement of

\title{
Response of biological productivity to North Atlantic marine front migration during the Holocene
}

David J. Harning et al.

Correspondence to: David J. Harning (david.harning@colorado.edu)

The copyright of individual parts of the supplement might differ from the CC BY 4.0 License. 
Table S1: Marine sediment core proxy records from Iceland's insular shelves.

\begin{tabular}{|c|c|c|c|}
\hline Marine core & Time Interval (ka BP) & Proxies & Reference \\
\hline MD99-2269 & 10 to 0 & diatoms & Andersen et al. (2004) \\
\hline MD99-2269 & 10 to 0 & $\begin{array}{l}\text { coccolithophores, } \mathrm{CaCO}_{3} \text {, } \\
\text { low-resolution benthic foram. }\end{array}$ & Giraudeau et al. (2004) \\
\hline MD99-2269 & 11.5 to 0 & $\mathrm{CaCO}_{3}$, quartz & Moros et al. (2006) \\
\hline MD99-2269 & 10 to 0 & dinocysts & Solignac et al. (2006) \\
\hline MD99-2269 & 4 to 0 & $\mathrm{Mg} / \mathrm{Ca}$ of benthic foram. & $\begin{array}{l}\text { Kristjánsdóttir et al. } \\
(2007 a)\end{array}$ \\
\hline MD99-2269 & 12 to 0 & tephra & $\begin{array}{l}\text { Kristjánsdóttir et al. } \\
(2007 b)\end{array}$ \\
\hline MD99-2269 & 12 to 0 & PSV age model & Stoner et al. (2007) \\
\hline MD99-2269 & 11.5 to 0 & diatoms & Justwan et al. (2008) \\
\hline MD99-2269 & 8 to 0 & $\begin{array}{l}\mathrm{IP}_{25} \text {, HBI III, T. quinqueloba, } \\
N \text {. pachyderma (s) }\end{array}$ & $\begin{array}{l}\text { Cabedo-Sanz et al. } \\
(2016)\end{array}$ \\
\hline MD99-2269 & 11.4 to 0.4 & $\begin{array}{l}\mathrm{Mg} / \mathrm{Ca} \text { and } \delta^{18} \mathrm{O} \text { of benthic and } \\
\text { planktic foram., } \delta^{13} \mathrm{C} \text { planktic } \\
\text { foram., alkenones }\end{array}$ & $\begin{array}{l}\text { Kristjánsdóttir et al. } \\
(2017)\end{array}$ \\
\hline JR51-GC35 & 10.2 to 0 & ${ }^{14} \mathrm{C}$ chronology, alkenones & $\begin{array}{l}\text { Bendle \& Rosell-Melé } \\
\text { (1997) }\end{array}$ \\
\hline $\begin{array}{l}\text { JR51-GC35 } \\
\text { and MD99- } \\
2264\end{array}$ & 12 to 0 & minerology & Andrews et al. (2014) \\
\hline JR51-GC35 & 8 to 0 & HBI, planktic foraminifera & $\begin{array}{lll}\begin{array}{l}\text { Cabedo-Sanz } \\
(2016)\end{array} & \text { et } & \text { al. } \\
\end{array}$ \\
\hline MD99-2275 & 1.2 to 0 & $\mathrm{IP}_{25}$ & Massé et al. (2008) \\
\hline MD99-2275 & 2 to 0 & diatoms & Jiang et al. (2005) \\
\hline $\begin{array}{l}\text { MD99-2275 } \\
\text { and }-2271\end{array}$ & 2 to 0 & $\begin{array}{l}\text { dinocysts, benthic and planktic } \\
\text { foram. and } \delta^{18} \mathrm{O} \text {, diatoms, } \\
\text { sedimentology }\end{array}$ & Eiríksson et al. (2006) \\
\hline MD99-2275 & 2 to 0 & alkenones & Sicre et al. (2008a) \\
\hline MD99-2275 & 4.5 to 0 & alkenones, magnetics & Sicre et al. (2008b) \\
\hline $\begin{array}{l}\text { B05-2006- } \\
\text { MC04 }\end{array}$ & 0.13 to 0 & $\begin{array}{l}\text { benthic and planktic foram., } \\
\text { diatoms, IRD }\end{array}$ & Knudsen et al. (2009) \\
\hline MD99-2275 & 2 to 0 & alkenones & Sicre et al. (2011) \\
\hline MD99-2275 & 15 to 0 & tephra & $\begin{array}{l}\text { Gudmundsdóttir et al. } \\
\text { (2012) }\end{array}$ \\
\hline MD99-2275 & 1 to 0 & $\begin{array}{l}\text { benthic and planktic foram. } \\
\text { and } \delta^{18} \mathrm{O}\end{array}$ & Knudsen et al. (2012) \\
\hline MD99-2275 & 9.3 to 0 & diatoms & Jiang et al. (2015) \\
\hline $\begin{array}{l}\text { HM107-04 and } \\
-05\end{array}$ & 14 to 0 & $\begin{array}{l}\text { grain size, minerology, MS, } \\
\text { water content, } \mathrm{CaCO}_{3} \text {, benthic } \\
\text { and planktic foram., tephra }\end{array}$ & Eiríksson et al. (2000a) \\
\hline HM107-03 & 4.5 to 0 & $\begin{array}{l}\text { benthic and planktic foram., } \\
\text { grain size, IRD, tephra }\end{array}$ & Eiríksson et al. (2000b) \\
\hline HM107-03 & 4.6 to 0 & diatoms & Jiang et al. (2002) \\
\hline $\begin{array}{l}\text { HM107-04 and } \\
-05\end{array}$ & 15.8 to 0 & $\begin{array}{l}\text { benthic and planktic foram. } \\
\text { and } \delta^{18} \mathrm{O} \text {, diatoms }\end{array}$ & Knudsen et al. (2004a) \\
\hline
\end{tabular}




\begin{tabular}{|c|c|c|c|}
\hline $\begin{array}{l}\text { HM107-03 and } \\
-02, \quad \text { MD99- } \\
2275\end{array}$ & 1.2 to 0 & $\begin{array}{l}\text { benthic and planktic foram. } \\
\text { and } \delta^{18} \mathrm{O} \text {, diatoms, IRD }\end{array}$ & Knudsen et al. (2004b) \\
\hline $\begin{array}{l}\text { MD99-2264 } \\
\text { and } \quad \text { B997 } \\
\text { cores }\end{array}$ & 36 to 0 & $\mathrm{IRD}, \mathrm{CaCO}_{3}, \mathrm{MS}$ & Geirsdóttir et a. (2002) \\
\hline $\begin{array}{l}\text { MD99-2256 } \\
\text { and }-2264\end{array}$ & 11.5 to 0 & benthic foram. and $\delta^{18} \mathrm{O}$ & Ólafsdóttir et al. (2012) \\
\hline MD99-2266 & 10.6 to 0.5 & $\begin{array}{l}\delta^{18} \mathrm{O} \text { of benthic } \text { foram., } \\
\mathrm{CaCO}_{3} \text {, MS, grain size, } \\
\text { carbonate, IRD }\end{array}$ & Quillmann et al. (2010) \\
\hline MD99-2266 & 8.4 to 7.6 & $\begin{array}{l}\mathrm{Mg} / \mathrm{Ca} \text { and } \delta^{18} \mathrm{O} \text { of benthic } \\
\text { foram., } \mathrm{CaCO}_{3}\end{array}$ & Quillmann et al. (2012) \\
\hline MD99-2266 & 10.7 to 0.3 & $\begin{array}{l}\text { C, N, GDGTs, alkenones, } n \text { - } \\
\text { alkanes }\end{array}$ & Moossen et al. (2013) \\
\hline MD99-2266 & 10.7 to 0.3 & $\begin{array}{l}\text { GDGTs, alkenones, } n \text {-alkanes } \\
\text { and } \delta \text { D }\end{array}$ & Moossen et al. (2015) \\
\hline MD99-2263 & 2 to 0 & $\begin{array}{l}\text { grain size, magnetics, } \\
\text { minerology, benthic and } \\
\text { planktic foram and } \delta^{18} \mathrm{O}, \mathrm{IP}_{25}\end{array}$ & Andrews et al. (2009) \\
\hline MD99-2263 & 12 to 0 & minerology, IRD, $\mathrm{CaCO}_{3}, \mathrm{IP}_{25}$ & Darby et al. (2017) \\
\hline $\begin{array}{l}\text { MD99-2271, } \\
2272,-2275\end{array}$ & 4.5 to 0 & $\begin{array}{l}\text { grain size, } \mathrm{C}, \mathrm{MS} \text {, water } \\
\text { content, } \mathrm{CaCO}_{3} \text {, benthic and } \\
\text { planktic foram., tephra }\end{array}$ & $\begin{array}{l}\text { Knudsen \& Eiríksson } \\
(2002)\end{array}$ \\
\hline $\begin{array}{l}\text { MD99-2271, - } \\
2273,-2275\end{array}$ & 4.5 to 0 & tephra and ${ }^{14} \mathrm{C}$ & Eiríksson et al. (2004) \\
\hline MD99-2273 & 0.9 to 0.5 & alkenones, $\mathrm{IP}_{25}$ & Sicre et al. (2013) \\
\hline MD99-2272 & 15 to 4 & $\begin{array}{l}\mathrm{IP}_{25} \text {, HBI III, sterols, } n- \\
\text { alkanols, tephra }\end{array}$ & Xiao et al. (2017) \\
\hline B997 cores & $<45$ & ${ }^{14} \mathrm{C}$ & Andrews et al. (2000) \\
\hline B997 cores & 4 to 0 & $\mathrm{MS}, \mathrm{CaCO}_{3}$, grain size, pollen & Andrews et al. (2001a) \\
\hline B997 cores & 5 to 0 & $\mathrm{CaCO}_{3}$ & Andrews et al. (2001b) \\
\hline B997 cores & 10.2 & tephra, magnetics & Andrews et al. (2002a) \\
\hline B997 cores & 36 to 0 & $\begin{array}{l}\text { grain size, } \mathrm{IRD}, \text { density, } \mathrm{MS} \text {, } \\
\text { magnetics, } \mathrm{C}, \mathrm{CaCO}_{3}\end{array}$ & Andrews et al. (2002b) \\
\hline B997 cores & 10 to 0 & coccolithophores, $\mathrm{CaCO}_{3}$ & $\begin{array}{l}\text { Andrews \& Giraudeau } \\
(2003)\end{array}$ \\
\hline B997 cores & 44 to 0 & $\begin{array}{l}\text { grain size, density, MS, } \\
\text { foram., tephra }\end{array}$ & $\begin{array}{l}\text { Andrews \& Helgadóttir } \\
(2003)\end{array}$ \\
\hline B997 cores & 14 to 0 & $\begin{array}{l}\text { benthic and planktic foram and } \\
\delta^{18} \mathrm{O}\end{array}$ & Castaneda et al. (2004) \\
\hline B997 cores & 10 to 0 & $\begin{array}{l}\text { benthic and planktic foram and } \\
\delta^{18} \mathrm{O}\end{array}$ & Smith et al. (2005) \\
\hline B997 cores & 2 to 0 & minerology & Andrews \& Eberl (2007) \\
\hline B997 cores & 12 to 0 & PSV & Andrews et al. (2008) \\
\hline B997 cores & 12 to 0 & minerology & Andrews (2009) \\
\hline B997 cores & 0.8 to 0 & $\begin{array}{l}\text { quartz, } \mathrm{CaCO}_{3}, \mathrm{IP}_{25}, \mathrm{HBI} \text { III, } \\
\text { GDGTs }\end{array}$ & Harning et al. (2019) \\
\hline
\end{tabular}




\begin{tabular}{|l|l|l|l|}
\hline $\begin{array}{l}\text { KN 158-4- } \\
\text { 72GGC } \\
\text { (Djúpall) }\end{array}$ & $\begin{array}{l}\text { carbonate, grain size, } \\
\text { minerology }\end{array}$ & Andresen et al. (2005) \\
\hline \multicolumn{3}{|l|}{} \\
\hline $\begin{array}{l}93030-006 \\
\text { LCF }\end{array}$ & 12.7 to $9.4\left({ }^{14} \mathrm{C}\right.$ yrs $)$ & $\begin{array}{l}\text { grain size, IRD, C, } \mathrm{CaCO}_{3}, \\
\text { MS, benthic and planktic } \\
\text { foram., tephra }\end{array}$ & Jennings et al. (2000) \\
\hline $93030-03 \mathrm{BC}$ & 0.4 to 0 & $\begin{array}{l}\mathrm{C}, \text { minerology, magnetics, } \\
\mathrm{CaCO}, \text { planktic foram. and } \\
\delta^{18} \mathrm{O} \text { and } \delta^{13} \mathrm{C}\end{array}$ & Jennings et al. (2001) \\
\hline
\end{tabular}
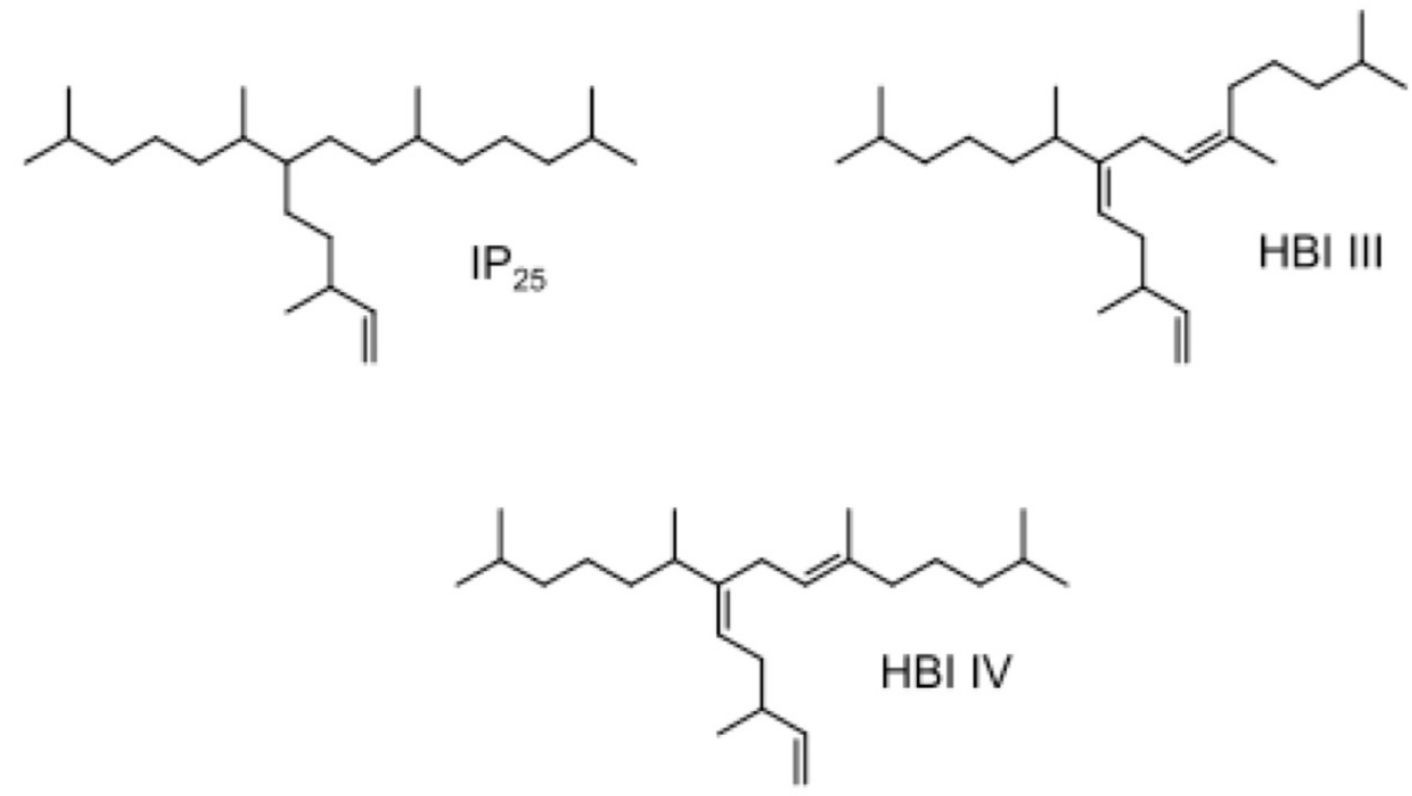

Fig. S1: Structures of highly branched isoprenoid (HBI) biomarkers discussed in the current study. 

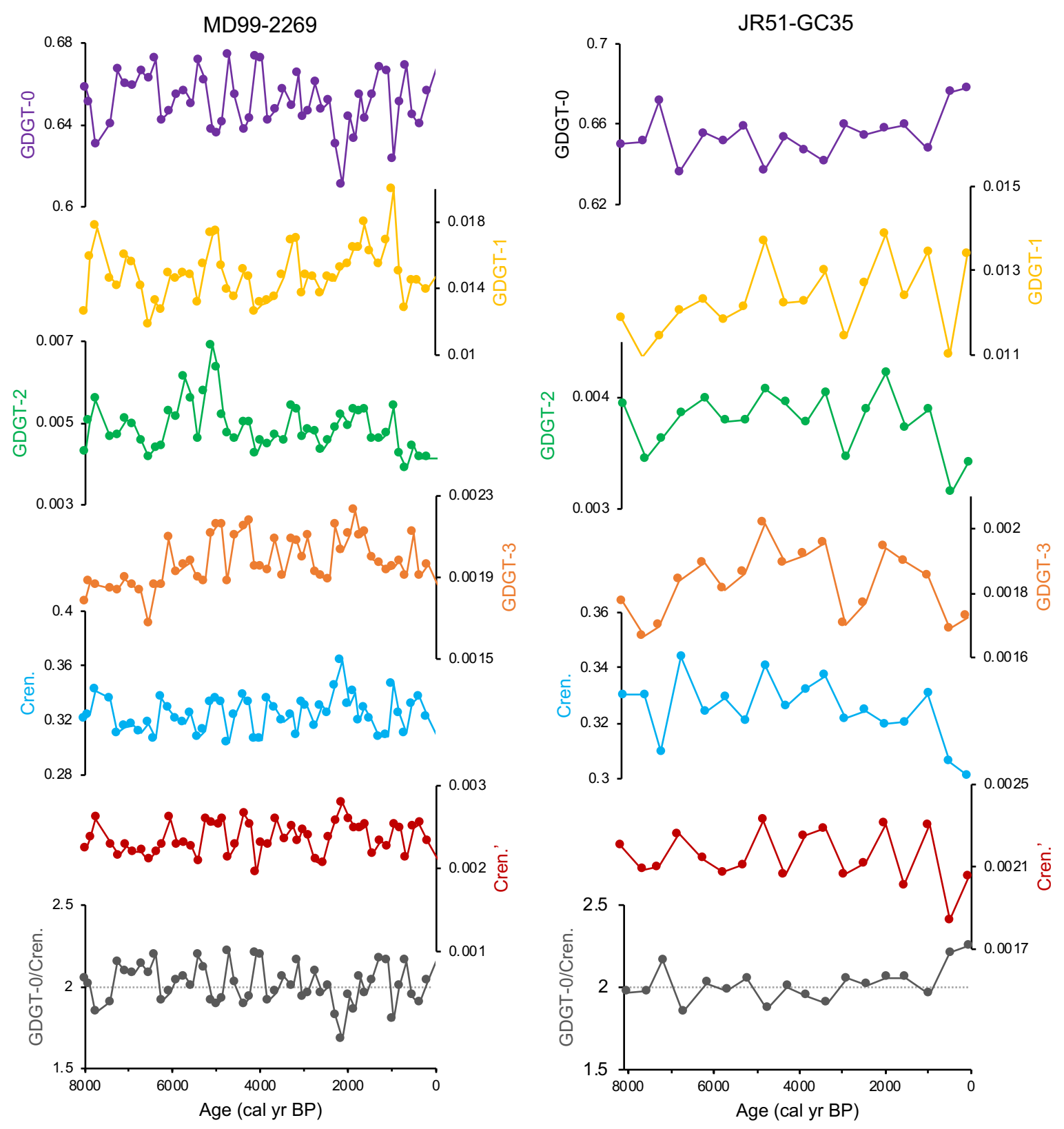

Fig. S2: Fractional abundances of individual GDGTs and GDGT-0/crenarchaeol ratios for MD99-2269 (left) and JR51-GC35 (right). GDGT-0/crenarchaeol values around and below 2 (grey dotted line) indicate that the GDGT pool is not altered by methanogenic contributors (e.g. Blaga et al., 2009). 


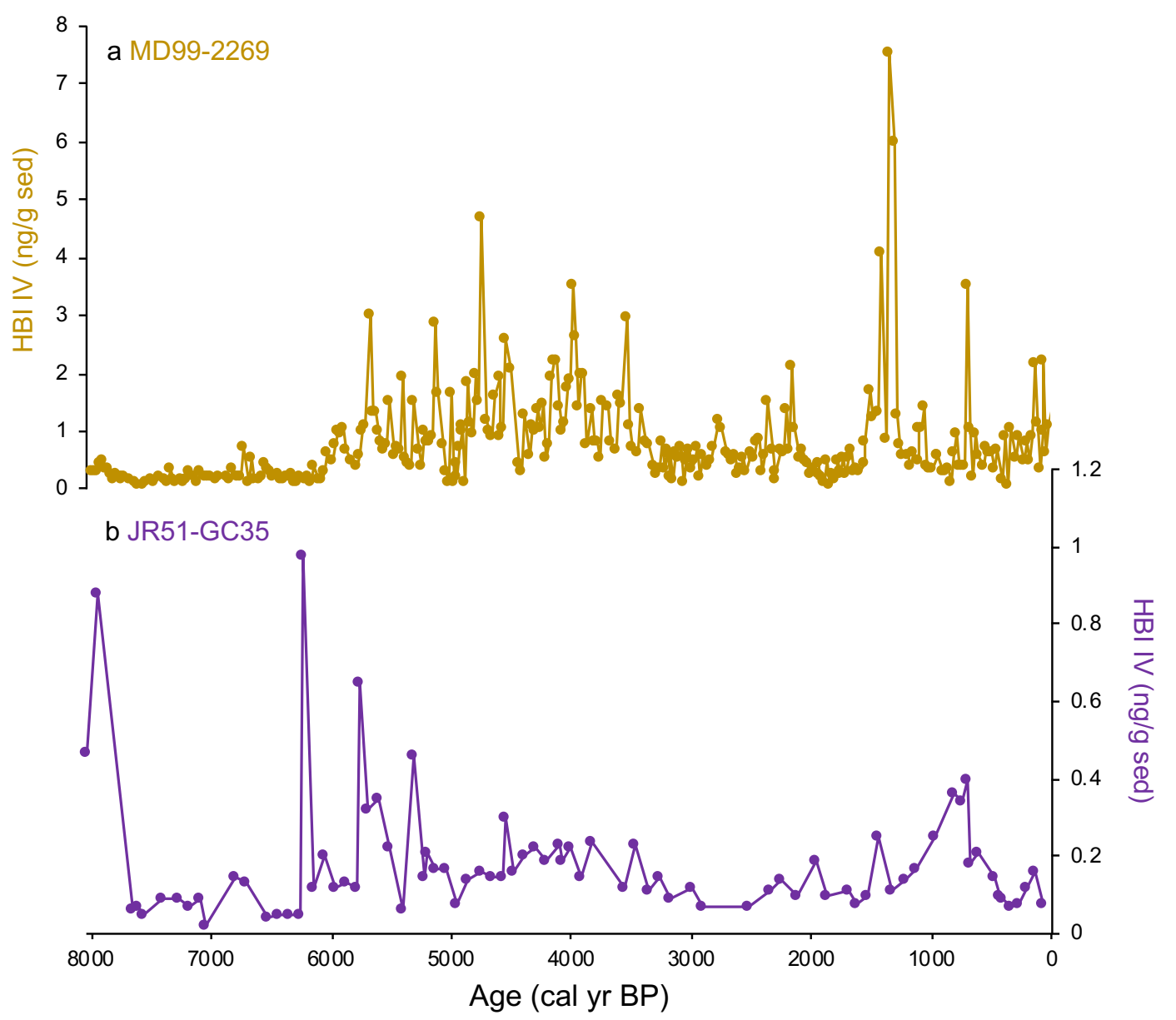

Fig. S3: Downcore HBI IV records from a) MD99-2269 and b) JR51-GC35. 


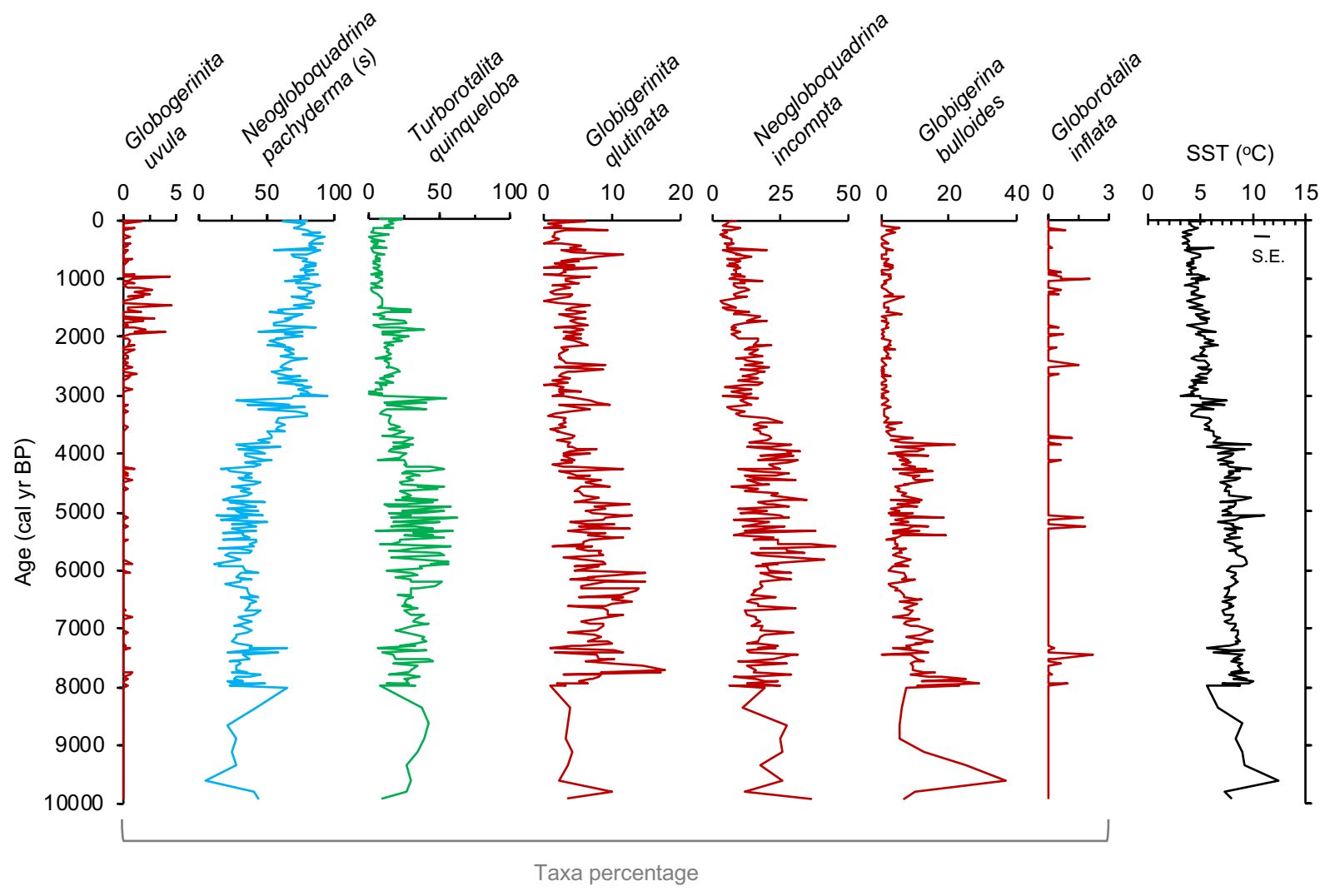

Fig. S4: Planktic foraminiferal species in MD99-2269 used to estimate summer SSTs over the last $10 \mathrm{ka} \mathrm{BP}$, with emphasis on high-resolution estimates for the past $8 \mathrm{cal} \mathrm{ka} \mathrm{BP}$. Colors indicate environmental preferences: $r e d=A$ tlantic Water species, blue $=$ Arctic, green=frontal species. 


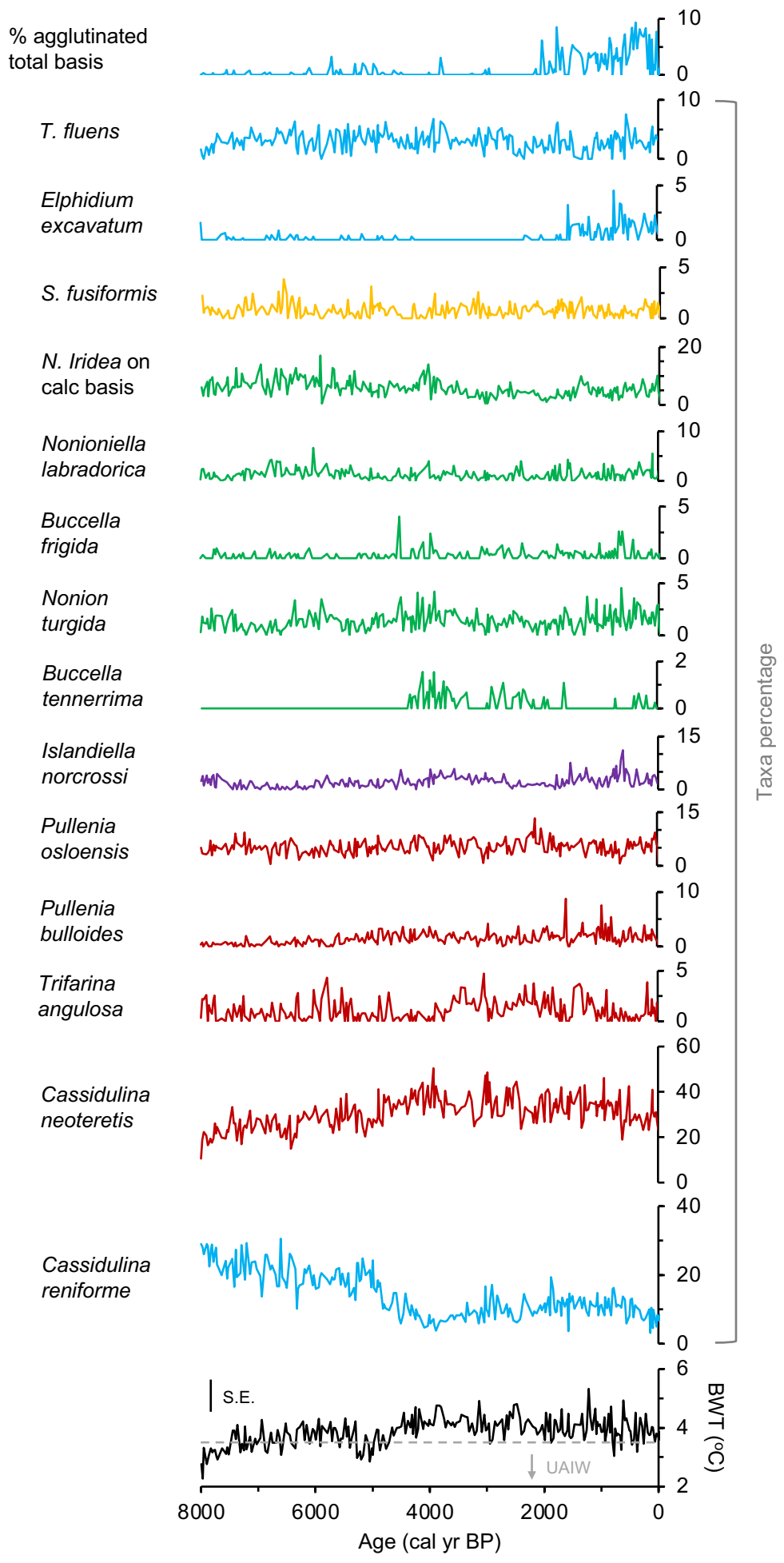

Fig S5: Select benthic species used to estimate BWT in MD99-2269 over the last 8 cal ka BP. Species colors indicate environmental preferences: red=Atlantic; blue $=$ Arctic, purple $=$ mixed Atlantic Water, green=productivity, yellow=indifferent. 


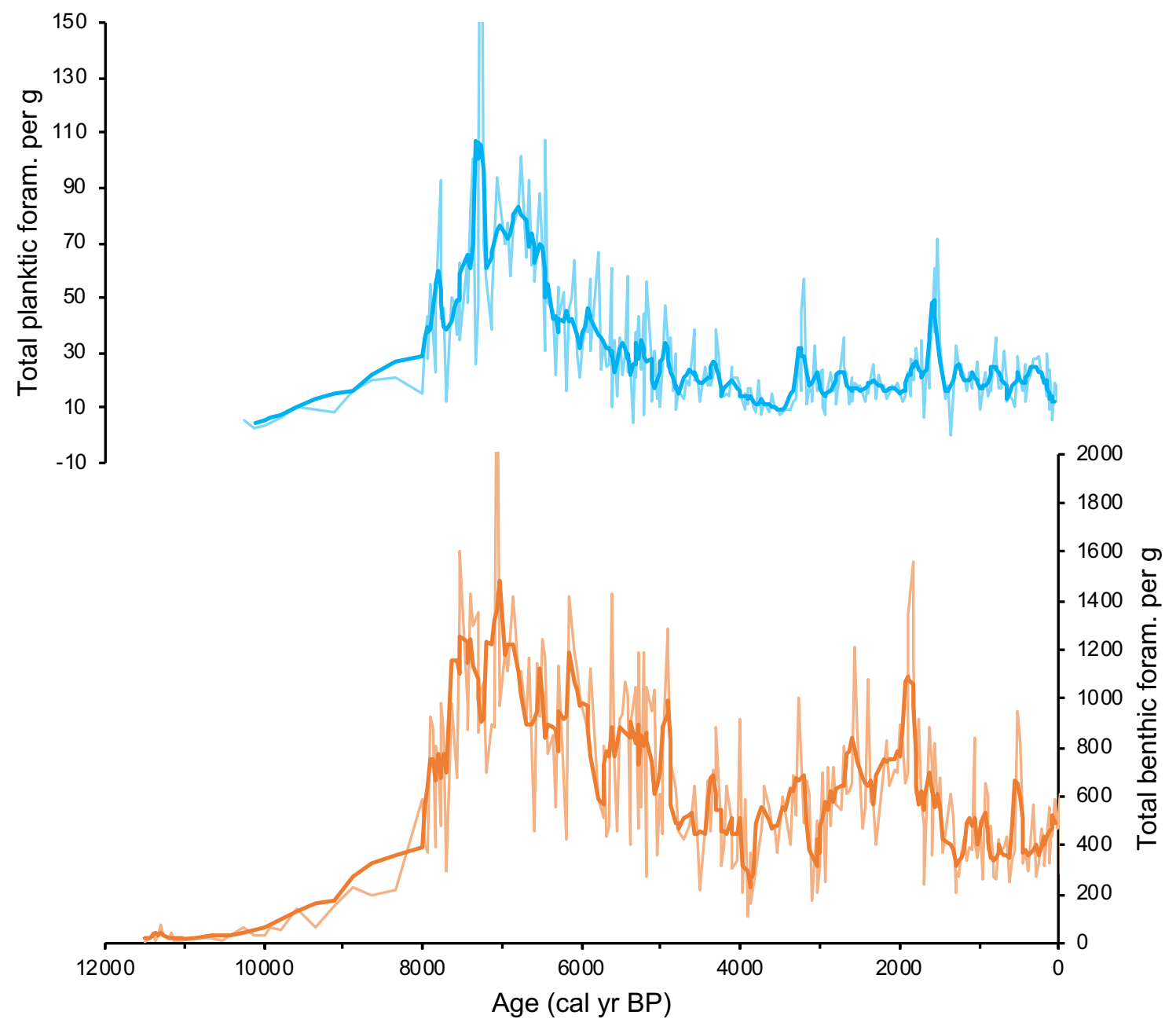

Fig. S6: Downcore records from MD99-2269 for planktic and benthic foraminifera per gram. Bold line is a 5-pt running mean. 


\section{References}

Andersen, C., Koç, N., Jennings, A.E., and Andrews, J.T.: Nonuniform response of the major surface currents in the Nordic Seas to insolation forcing: Implications for the Holocene climate variability. Paleoceanography, 19, 1-16, 2004.

Andresen, C.S., Bond, G., Kuijpers, A., Knutz, P.C., and Björck, S.: Holocene climate variability at multidecadal time scales detected by sedimentological indicators in a shelf core NW off Iceland. Mar. Geol., 214, 323-338, 2005.

Andrews, J.T.: Seeking a Holocene drift ice proxy: non-clay mineral variations from the SW to N-central Iceland shelf: trends, regime shifts, and periodicities. J. Quat. Sci., 24, 664-676, 2009.

Andrews, J.T., Belt, S.T., Olafsdottir, S., Massé, G., and Vare, L.L.: Sea ice and marine climate variability for NW Iceland/Denmark Strait over the last 2000 cal. yr BP. Holocene, 19, 775-784, 2009.

Andrews, J.T., Bigg, G.R., and Wilton, D.J.: Holocene ice-rafting and sediment transport from the glaciated margin of East Greenland $\left(67-70^{\circ} \mathrm{N}\right)$ to the N Iceland shelves: detecting and modelling changing sediment sources. Quat. Sci. Rev., 91, 204-217, 2014.

Andrews, J.T., Caseldine, C., Weiner, N.J., and Hatton, J.: Late Quaternary (ca. 4 ka) marine and terrestrial environmental change in Reykharfjordur, north Iceland: climate and/or settlement? J. Quat. Sci., 16, 133-144, 2001a.

Andrews, J.T., and Eberl, D.D.: Quantitative mineralogy of surface sediments on the Iceland shelf, and application to down-core studies of Holocene ice-rafted sediments. J. Sediment. Res.: 77, 469-479, 2007

Andrews, J.T., Geirsdóttir, Á., Hardardóttir, J., Principato, S., Grönvold, K., Kristjánsdóttir, G.B., Helgadóttir, G., Drexler, J., and Sveinbjörnsdóttir, A.E.: Distribution, sediment magnetism and geochemistry of the Saksunarvatn (10 $180 \pm 60$ cal. yr BP) tephra in marine, lake, and terrestrial sediments, northwest Iceland. J. Quat. Sci., 17, 731-745, $2002 \mathrm{a}$

Andrews, J.T., and Giraudeau, J.: Multi-proxy records showing significant Holocene environmental variability on the inner North Iceland Shelf (Hunafloi). Quat. Sci. Rev., 22, 175-193, 2003.

Andrews, J.T., Hardardóttir, J., Geirsdóttir, Á., and Helgadóttir, G.: Late Quaternary ice extent and depositional history from the Djúpall trough, off the Vestfirðir peninsula, north-west Iceland: A stacked 36 cal environmental record. Polar Res., 21, 211-226, 2002b.

Andrews, J.T., Harðardóttir, J., Helgadóttir, G., Jennings, A.E., Geirsdóttir, Á., Sveinbjörnsdóttir, Á.E., Schoolfield, S., Kristjánsdóttir, G.B., Smith, L.M., Thors, K., and Syvitski, J.: The N and W Iceland Shelf: insights into Last Glacial Maximum ice extent and deglaciation based on acoustic stratigraphy and basal radiocarbon AMS dates. Quat. Sci. Rev., 19, 619-631, 2000.

Andrews, J.T., Hardardóttir, J., Stoner, J.S., and Principato, S.: Holocene sediment magnetic properties along a transect from Ísafjarðardjúp to Djúpall, Northwest Iceland. Arct., Antarct., Alp. Res., 40, 1-14, 2008.

Andrews, J.T., and Helgadóttir, G.: Late Quaternary ice cap extent and deglaciation, Húnaflóaáll, Northwest Iceland: Evidence from marine cores. Arct., Antarct., Alp. Res., 35, 218-232, 2003.

Andrews, J.T., Helgadottir, G., Geirsdóttir, A., and Jennings, A.E.: Multi-century-scale records of carbonate (hydrographic?) variability on the N. Iceland margin over the last 5000 years. Quat. Res., 56, 199-206, $2001 \mathrm{~b}$.

Andrews, J.T., Kihl, R., Kristjansdottir, G.B., Smith, L.M., Helgadottir, G., Geirsdóttir, A., and Jennings, A.E.: Holocene sediment properties of the East Greenland and Iceland continental shelves bordering Denmark strait $\left(64^{\circ}-\right.$ $\left.68^{\circ} \mathrm{N}\right)$, North Atlantic. Sedimentology, 49, 5-24, 2002b 
Bendle, J.A.P., and Rosell-Melé, A.: High-resolution alkenone sea surface temperature variability on the North Icelandic Shelf: implications for Nordic Seas palaeoclimatic development during the Holocene. Holocene, 17, 9-24, 2007.

Blaga, C.I., Reichart, G.-J., Heiri, O., and Sinninghe Damsté, J.S.: Tetraether membrane lipid distribution in watercolumn particulate matter and sediments: A study from 47 European lakes along a north-south transect. J. Paleolimnol., 41, 535-540, 2009.

Cabedo-Sanz, P., Belt, S.T., Jennings, A.E., Andrews, J.T., and Geirsdóttir, Á.: Variability in drift ice export from the Arctic Ocean to the North Icelandic Shelf over the last 8000 years: A multi-proxy evaluation. Quat. Sci. Rev., 146, 99-115, 2016.

Castañeda, I.S., Smith, L.M., Kristjánsdóttir, G.B., and Andrews, J.T.: Temporal changes in Holocene $\delta^{18} \mathrm{O}$ records from northwest and central North Iceland Shelf. J. Quat. Sci., 19, 321-334, 2004.

Darby, D.A., Andrews, J.T., Belt, S.T., Jennings, A.E., and Cabedo-Sanz, P.: Holocene cyclic records of ice-rafted debris and sea ice variations on the East Greenland and Northwest Iceland margins. Arct., Antarct., Alp. Res., 49, 649$672,2017$.

Eiríksson, J., Bartels-Jonsdottir, H.B., Cage, A.G., Gudmundsdottir, E.R., Klitgaard- Kistensen, D., Marret, F., Rodrigues, T., Abrantes, F., Austin, W.E.N., Jiang, H., Knudsen, K.L., and Sejrup, H.P.: Variability of the North Atlantic current during the last 2000 years based on shelf bottom water and sea surface temperatures along an open ocean/shallow marine transect in western Europe. Holocene, 16, 1017-1019, 2006.

Eiríksson, J., Knudsen, K.L., Haflidason, H., and Henriksen, P.: Late-glacial and Holocene palaeoceanography of the North Icelandic Shelf. J. Quat. Sci., 15, 23-42, 2002a.

Eiríksson, J., Knudsen, K.L., Haflidason, H., and Heinemeier, J.: Chronology of late Holocene climatic events in the northern North Atlantic based on AMS ${ }^{14} \mathrm{C}$ dates and tephra markers from the volcano Hekla, Iceland. J. Quat. Sci., $15,573-580,2002 b$.

Eiríksson, J., Larsen, G., Knudsen, K.L., Heinemeier, J., and Símonarson, L.A.: Marine reservoir age variability and water mass distribution in the Iceland Sea. Quat. Sci. Rev., 23, 2247-2268, 2004.

Geirsdóttir, Á., Andrews, J.T., Ólafsdóttir, S., Helgadóttir, G., and Harðardóttir, J.: A 36 Ky record of iceberg rafting and sedimentation from north-west Iceland. Polar Res., 21, 291-298, 2002.

Giraudeau, J., Jennings, A.E., and Andrews, J.T.: Timing and mechanisms of surface and intermediate water circulation changes in the Nordic Sea over the last 10000 cal years: A view from the North Iceland Shelf. Quat. Sci. Rev., 23, 2127-2139, 2004.

Gudmundsdóttir ER, Larsen G, and Eiríksson, J.: Tephra stratigraphy on the North Icelandic shelf: extending tephrochronology into marine sediments off North Iceland. Boreas, 41, 719-734, 2012.

Harning, D.J., Andrews, J.T., Belt, S.T., Cabedo-Sanz, P., Geirsdóttir, Á., Dildar, N., Miller, G.H., and Sepúlveda, J.: Sea ice control on winter subsurface temperatures of the North Iceland Shelf during the Little Ice Age: A TEX 86 calibration case study. Paleoceanogr. Paleoclimatol., 34, 1006-2021, 2019.

Jennings, A.E., Hagen, S., Hardardóttir, J., Stein, R., Ogilvie, A.E.J., and Jonsdóttir, I.: Oceanographic change and terrestrial human impacts in a post A.D. 1400 sediment record from the southwest Iceland shelf. Clim. Chang., 48, 83-100, 2001.

Jennings, A., Syvitski, J., Gerson, L., Grönvold, K., Geirsdóttir, Á., Hardardóttir, J., Andrews, J., and Hagen, S.: Chronology and paleoenvironments during the late Weichselian deglaciation of the southwest Iceland shelf. Boreas, 29, 167-183, 2000. 
Jiang, H., Eiríksson, J., Schultz, M., and Knudsen, K.L., Seidenkrantz, M.S.: Evidence for solar forcing of sea surface temperature on the North Icelandic Shelf during the late Holocene. Geology, 33, 73-76, 2005.

Jiang, H., Seidenkrantz, M.S., Eiriksson, J., and Knudsen, K.L.: Late-Holocene summer sea-surface temperature based on a diatom record from the north Iceland shelf. Holocene, 137-147, 2002.

Jiang, H., Muscheler, R., Björck, S., Seidenkrantz, M.-S., Olsen, J., Sha, L., Sjolte, J., Eiríksson, J., Ran., L., Knudsen, K.-L., and Knudsen, M.F.: Solar forcing of Holocene summer sea-surface temperatures in the northern North Atlantic. Geology, 43, 2-5, 2015.

Justwan, A., Koc, N., and Jennings, A.E.: Evolution of the Irminger and East Icelandic Current systems through the Holocene, revealed by diatom-based sea surface temperature reconstructions. Quat. Sci. Rev., 27, 1571-1582, 2008.

Knudsen, K.L., Jiang, H., Jansen, E., Eiríksson, J., Heinemeier, J., and Seidenkrantz, M.S.: Environmental changes off North Iceland during the deglaciation and the Holocene: foraminifera, diatoms and stable isotopes. Mar.

Micropaleontol., 50, 273-305, 2004a.

Knudsen, K.L., and Eiríksson, J.: Application of tephrochronology to the timing and correlation of palaeoceanographic events records in Holocene and Late Glacial shelf sediments off North Iceland. Mar. Geol., 191, 165-188, 2002.

Knudsen, K.L., Eiríksson, J., and Bartels-Jónsdóttir, H.B.: Oceanographic changes through the last millennium off North Iceland: Temperature and salinity reconstructions based on foraminifera and stable isotopes. Mar. Micropaleontol., 84-85, 54-73, 2012.

Knudsen, K.L., Eiríksson, J., Jansen, E., Jiang, H., Rytter, F., and Gudmundsdottir, E.R.: Palaeoceanographic changes off North Iceland through the last 1200 years: foraminifera, stable isotopes, diatoms and ice rafted debris. Quat. Sci. Rev., 23, 2231-2246, 2004b.

Knudsen, K.L., Eiríksson, Jiang, H., and Jónsdóttir, I.: Paleoceanography and cliate changes off North Iceland during the last millennium: comparison of foraminifera, diatoms and ice-rafted debris with instrumental and documentary data. J. Quat. Sci., 24, 457-468, 2009.

Kristjánsdóttir, G.B., Lea, D.W., Jennings, A.E., Pak, D.K., and Belanger, C.: New spatial Mg/Ca-temperature calibrations for three Arctic, benthic foraminifera and reconstruction of north Iceland shelf temperature for the past 4000 years. Geochem., Geophys., Geosyst., 8, 1-27, 2007a

Kristjánsdóttir, G.B., Stoner, J.S., Jennings, A.E., Andrews, J.T., and Grönvold, K.: Geochemistry of Holocene cryptotephras from the North Iceland Shelf (MD99-2269): intercalibration with radiocarbon and palaeomagnetic chronostratigraphies. Holocene, 17, 155-176, $2007 \mathrm{~b}$.

Kristjánsdóttir, G.B., Moros, M., Andrews, J.T., and Jennings, A.E.: Holocene $\mathrm{Mg} / \mathrm{Ca}$, alkenones, and light stable isotope measurements on the outer North Iceland shelf (MD99-2269): A comparison with other multi-proxy data and sub-division of the Holocene. Holocene, 26, 55-62, 2017.

Massé, G., Rowland, S.J., Sicre, M.-A., Jacob, J., Jansen, E., and Belt, S.T.: Abrupt climate changes for Iceland during the last millennium: Evidence from high resolution sea ice reconstructions. Earth Planet. Sci. Lett., 269, 565-569, 2008.

Moossen, H., Abell, R., Quillmann, U., and Bendle, J.: Holocene changes in marine productivity and terrestrial organic carbon inputs into an Icelandic fjord: Application of molecular and bulk organic proxies. Holocene, 23, 1699-1710, 2013..

Moossen, H., Bendle, J., Seki, O., Quillmann, U., and Kawamura, K.: North Atlantic Holocene climate evolution recorded by high-resolution terrestrial and marine biomarker records. Quat. Sci. Rev., 129, 111-127, 2015. 
Moros, M., Andrews, J.T., Eberl, D.D., and Jansen, E.: Holocene history of drift ice in the northern North Atlantic: Evidence for differential spatial and temporal modes. Paleoceanography, 21, 1-10, 2006.

Ólafsdóttir, S., Jennings, A.E:, Geirsdóttir, Á., Andrews, J., and Miller, G.H.: Holocene variability of the North Atlantic Irminger currents on the south- and northwest shelf of Iceland. Mar. Micropaleontol., 77, 101-118, 2010.

Quillmann, U., Jennings, A., and Andrews, J.: Reconstructing Holocene palaeoclimate and palaeoceanography in Ísafjarðardjúp, northwest Iceland, from two fjord records overprinted by relative sea-level and local hydrographic changes. J. Quat. Sci., 25, 1144-1159, 2010.

Quillmann, U., Marchitto, T.M., Jennings, A.E., Andrews, J.T., and Friestad, B.F.: Cooling and freshening at 8.2 ka on the NW Iceland Shelf recorded in paired $\delta^{18} \mathrm{O}$ and $\mathrm{Mg} / \mathrm{Ca}$ measurements of the benthic foraminifer Cibicides lobatulus. Quat. Res., 78, 528, 539, 2012.

Sicre, M.-A., Hall, I.R., Mignot, J., Khodri, M., Ezat, U., Truong, M.-X., Eiriksson, J., and Knudsen, K.-L.: Sea surface temperature variability in the subpolar Atlantic over the last two millennia. Paleoceanography, 26, 1-10, 2011.

Sicre, M.-A., Jacob, J., Ezat, U., Rousse, S., Kissel, K., Eiriksson, J., Knudsen, K.-L., Jansen, E., and Turon, J.L.: Decadal variability of sea surface temperatures off North Iceland over the last 2000 yrs. Earth Planet. Sci. Lett., 268, $137-142,2008 \mathrm{a}$.

Sicre, M.-A., Khodri, M., Mignot, J., Eiriksson, J., Knudsen, K.-L., Ezat, U., Closset, I., Nogues, P., and Massé, G.: Sea surface temperature and sea ice variability in the subpolar North Atlantic from explosive volcanism of the late thirteenth century. Geophys. Res. Lett., 40, 5526-5530, 2013.

Sicre, M.-A., Yiou, P., Eiriksson, J., Ezat, U., Guimbaut, E., Dahhaoui, I., Knudsen, K.-L., Jansen, E., and Turon, J.L.: A 4500-year reconstuction of sea surface temperature variability at decadal time-scales off North Iceland. Quat. Sci. Rev., 27, 2041-2047, 2008b.

Smith, L.M., Andrews, J.T., Castañeda, I.S., Kristjánsdóttir, G.B., Jennings, A.E., and Sveinbjörnsdóttir, Á.E.: Temperature reconstructions for SW and N Iceland waters over the last $10 \mathrm{cal}$ ka based on $\delta^{18} \mathrm{O}$ records from planktic and benthic foraminifera. Quat. Sci. Rev., 24, 1723-1740, 2005.

Solignac, S., Giraudeau, J., and de Vernal, A.: Holocene sea surface conditions in the western North Atlantic: Spatial and temporal heterogeneities. Paleoceanography, 21, 1-6, 2006

Stoner, J.S., Jennings, A., Kristjánsdóttir, G.B., Dunhill, G., Andrews, J.T., and Hardardóttir, J.: A paleomagnetic approach toward refining Holocene radiocarbon-based chronologies: Paleoceanographic records from the north Iceland (MD99-2269) and east Greenland (MD99-2322) margins. Paleoceanography, 22, 1-23, 2007.

Xiao, X., Zhao, M., Knudsen, K.L., Sha, L., Eiríksson, J., Gudmundsdóttir, E., Jiang, H., and Guo, Z.: Deglacial and Holocene sea-ice variability north of Iceland and response to ocean circulation changes. Earth Planet. Sci. Lett., 472, 14-24, 2017. 